\title{
KOMPETENSI GURU PENDIDIKAN JASMANI SEKOLAH DASAR
}

\author{
Mulyana \\ Fakultas Ilmu Keolahragaan, Universitas Negeri Jakarta, Jln. Pemuda Jakarta Timur \\ HP: 081310872249, email: gunmly@yahoo.co.id
}

\begin{abstract}
This study aims to determine the competency of Physical Education Teacher in Elementary Schools (SD). The study population are all Physical Education Teachers. Samples taken from 30 teachers, while the technique is using simple random sampling. The method used is descriptive survey. Data obtained using a likert scale instrument to capture data; pedagogic competence, personal competence, sosial competence, and professional competence. The results of this study concluded that teachers of Physical Education in Primary Schools have the ability to teach well the field of Physical Education, in charge of teaching materials. But teachers are still weak in the mastery of the concept of sports science. Not all teachers can use information and communication technology in teaching Physical Education. The ability of teachers to develop themselves in a professional activity that is also not adequate.
\end{abstract}

Keywords: Competence, Physical Education Teacher

\begin{abstract}
Abstrak
Penelitian ini bertujuan untuk mengetahui kompetensi guru Pendidikan Jasmani Sekolah Dasar (SD). Metode penelitian yang digunakan adalah survey deskriptif. Data diperoleh dengan menggunakan instrumen skala likert untuk menjaring data; kompetensi pedagogik, kompetensi kepribadian, kompetensi sosial, dan kompetensi professional. Hasil penelitian ini menyimpulkan bahwa guru Pendidikan Jasmani di SD mampu mengajar Pendidikan Jasmani yang baik dan menguasi materi ajar. Namun disisi lain, masih terdapat kelemahan dalam penguasaan konsep keilmuan olah raga, selain itu tidak semua guru dapat memanfaatkan teknologi informasi dan komunikasi dalam pembelajaran Pendidikan Jasmani. Kemampuan guru dalam mengembangkan diri pada kegiatan profesional juga belum memadai.
\end{abstract}

Kata kunci: Kompetensi, Pendidikan Guru Fisika

\section{PENDAHULUAN}

Guru memegang peranan yang sangat penting dan strategis dalam upaya mem-bentuk watak bangsa dan mengembangkan potensi siswa dalam kerangka pembangunan pendidikan di Indonesia. Oleh sebab itu, diperlukan guru yang memiliki kemampuan yang maksimal untuk mewujudkan tujuan pendidikan nasional dan diharapkan secara berkesinambungan mereka dapat meningkatkan kompetensinya, baik kompetensi pedagogik, kepribadian, sosial, maupun profesional. Usman (2002: 15) menyatakan bahwa guru yang profesional adalah orang yang memiliki kemampuan dan keahlian khusus dalam bidang keguruan, sehingga ia mampu melakukan tugas dan fungsinya seba-gai guru dengan kemampuan yang maksimal. Kepribadian guru merupakan hasil pembentukan pengalaman belajar yang bukan hanya terjadi dalam proses pembelajaran secara lang-sung, tetapi terintegrasi dari dampak ikutan (nurturant effect) kegiatan pembelajaran dan pengalaman pengalaman panjang sebelum-nya. Kemampuan guru berinteraksi dengan peserta didik adalah suatu proses transaksional yang sangat khas dan nonrutin. Hal ini berbeda dengan interaksi guru dengan sejawat, orang tua, dan masyarakat sekitar yang bersifat kontekstual. Sifat dan kualitas interaksi antara guru dengan peserta didik menuntut kecakapan memilih strategi yang relevan karena sifat 
interaksi berkembang secara dinamis. Sementara karakteristik subjek dengan siapa ia berkomunikasi berbeda satu dengan lainnya baik karena faktor budaya, usia dan kedudukannya.

Sosok utuh seorang lulusan program pendidikan profesi guru secara generik tertuang dalam Standar Kompetensi Guru (Permen no. 16 tahun 2007). Kompetensi guru tersebut semula disusun secara utuh, namun pada akhir proses peresmiannya menjadi peraturan menteri, diklasifikasikan ke dalam 4 kategori kompetensi dengan judul seperti tertera pada Peraturan Pemerintah Nomor 19 tahun 2005 tentang Standar Nasional Pendidikan.

Louise Moqvist (2003) mengemukakan, "competency has been defined in the light of actual circumstances relating to the individual and work. Sementara itu Len Holmes (1992) seperti dikutip Akhmad Sudrajat (2008) bahwa: "A competence is a description of something which a person who works in a given occupational area should be able to do. It is a description of an action, behaviour or outcome which a person should be able to demonstrate." Dari kedua pendapat di atas kita dapat menarik benang merah bahwa kompetensi pada dasarnya merupakan gambaran Tantang apa yang seyogiyanya dapat dilakukan (be able to do) seseorang dalam suatu pekerjaan, berupa kegiatan, perilaku dan hasil yang seyogyanya dapat ditampilkan atau ditunjukkan.

Agar dapat melakukan (be able to do) sesuatu dalam pekerjaannya, tentu saja seseorang harus memiliki kemampuan (ability) dalam bentuk pengetahuan (knowledge), sikap (attitude) dan keterampilan (skill) yang sesuai dengan bidang pekerjaannya. Mengacu pada pengertian kompetensi di atas, maka dalam hal ini kompetensi guru dapat dimaknai sebagai gambaran tentang apa yang seyogyanya dapat dilakukan seseorang guru dalam melaksanakan pekerjaannya, baik berupa kegiatan, berperilaku maupun hasil yang dapat ditunjukkan.
Kompetensi diartikan sebagai pengetahuan, keterampilan, dan nilai-nilai dasar yang direfleksikan dalam kebiasaan berpikir dan bertindak. Arti lain dari kompetensi adalah spesifikasi dari pengetahuan, keterampilan, dan sikap yang dimiliki seseorang serta penerapannya di dalam pekerjaan, sesuai dengan standar kinerja yang dibutuhkan oleh lapangan.

Dengan demikian, kompetensi yang dimiliki oleh setiap guru akan menunjukkan kualitas guru yang sebenarnya. Kompetensi tersebut akan terwujud dalam bentuk penguasaan pengetahuan, keterampilan maupun sikap profesional dalam menjalankan fungsi sebagai guru.

Berdasarkan pengertian tersebut, Stan-dar Kompetensi Guru adalah suatu pernyataan tentang kriteria yang dipersyaratkan, ditetap-kan dan disepakati bersama dalam bentuk pe-nguasaan pengetahuan, keterampilan dan si-kap bagi seorang tenaga kependidikan sehing-ga layak disebut kompeten.

Standar Kompetensi Guru (Depdiknas, 2006). meliputi tiga komponen yaitu: (1) Komponen Kompetensi Pengelola-an Pembelajaran dan Wawasan Kependidik-an; (2) Komponen Kompetensi Akademik/ Vokasional sesuai materi pembelajaran; (3) Pengembangan Profesi. Masing-masing komponen kompetensi mencakup seperangkat kompetensi. Selain ketiga komponen kompetensi tersebut, guru sebagai pribadi yang utuh harus juga memiliki sikap dan kepribadian yang positip. Sikap dan kepribadian tersebut senantiasa me-lingkupi dan melekat pada setiap komponen kompetensi yang menunjang profesi guru. Telah dinyatakan bahwa Standar Kompetensi Guru meliputi 3 (tiga) komponen kompetensi dan masingmasing komponen kompetensi terdiri atas beberapa unit kompetensi. Secara keseluruhan, standar kompetensi guru terdiri dari tiga kompetensi, yaitu kompetensi pedagogik, kompetensi kepribadian, kompetensi sosial, dan kompetensi profesional. 
Kompetensi pedagogik ini meliputi (1) menguasai karakteristik peserta didik dari aspek fisik, moral, sosial, kultural, emosional, dan intelektual, (2) menguasai teori belajar dan prinsip-prinsip pembelajaran yang mendidik, (3) menguasai kurikulum yang terkait dengan bidang pengembangan yang diampu, (4) terampil melakukan kegiatan pengembangan yang mendidik, (5) memanfaatkan teknologi infomasi dan komunikasi untuk kepentingan penyelenggaraan kegiatan pengembangan yang mendidik, (6) memfasilitasi pengembangan potensi peserta didik untuk mengaktualisasikan berbagai potensi yang dimiliki, (7) berkomunikasi secara efektif, empatik, dan santun dengan peserta didik, (8) terampil melakukan penilaian dan evaluasi proses dan hasil belajar, (9) memanfaatkan hasil penilaian dan evaluasi untuk kepentingan pembelajaran, dan (10) melakukan tindakan reflektif untuk peningkatan kualitas pembelajaran.

Kompetensi kepribadian meliputi (1) bertindak sesuai dengan norma agama, hukum, sosial, dan kebudayaan nasional Indonesia, (2) menampilkan diri sebagai pribadi yang jujur, berakhlak mulia, dan teladan bagi peserta didik dan masyarakat, (3) menampilkan diri sebagai pribadi yang mantap, stabil, dewasa, arif, dan berwibawa, (4) menunjukkan etos kerja, tang-gungjawab yang tinggi, rasa bangga menjadi guru, dan rasa percaya diri, dan (5) menjunjung tinggi kode etik profesi guru.

Kompetensi sosial meliputi (1) bersikap inklusif, bertindak objektif, serta tidak diskriminatif karena pertimbangan jenis kelamin, agama, ras, kondisi fisik, latar belakang keluarga, dan status sosial ekonomi, (2) berkomunikasi secara efektif, empatik, dan santun dengan sesama pendidik, tenaga kependidikan, orang tua, dan masyarakat, (3) beradaptasi di tempat bertugas di seluruh wilayah Republik Indonesia yang memiliki keragaman sosial budaya, dan (4) berkomunikasi dengan komunitas profesi sendiri dan profesi lain secara lisan dan tulisan atau bentuk lain.
Kompetensi profesional meliputi (1) menguasai materi, struktur, konsep, dan pola pikir keilmuan yang mendukung mata pelajar-an yang diampu, (2) menguasai standar kom-petensi dan kompetensi dasar mata pelajar-an/bidang pengembangan yang diampu, (3) mengembangkan materi pembelajaran yang diampu secara kreatif, (4) mengembangkan keprofesionalan secara berkelanjutan dengan melakukan tindakan reflektif, (5) memanfaat-kan teknologi informasi dan komunikasi untuk berkomunikasi dan mengembangkan diri.

Berdasarkan penjelasan di atas peneli-tian ini menfokuskan pada kompetensi peda-gogik dan kompetensi profesional. Penelitian ini dilakukan bertujuan untuk mengetahui ba-gaimana kompetensi Guru Pendidikan Jasma-ni Sekolah Dasar se-Kecamatan Pulogadung Jakarta Timur.

\section{METODOLOGI PENELITIAN}

Penelitian dilakukan di Sekolah Dasar se-Kecamatan Pulogadung pada bulan September-Desember 2007. Metode penelitian menggunakan pendekatan survey deskriptif yang berdasarkan pengamatan. Untuk mengumpulkan data, penulis memberikan angket kepada Guru Pendidikan Jasmani yang meng-ajar di sekolah dasar yang ada di Kecamatan Pulogadung. Populasi dalam penelitian ini adalah seluruh Guru Pendidikan Jasmani Se-kolah Dasar seKecamatan Pulogadung, baik guru pria maupun wanita yang berstatus tetap maupun hononer.

Teknik pengumpulan sampel menggunakan acak sederhana dan didapat 30 Guru Pendidikan Jasmani Sekolah Dasar seKecamatan Pulogadung. Penelitian menggunakan model skala Likert untuk Kompetensi Pedagogik, Kompetensi Kepribadian, Kompetensi Sosial, Kompetensi Profesional. Untuk Kompetensi Pedagogik dari 40 pertanyaan, 9 pertanyaan dinyatakan drop dan 31 pertanyaan valid. Un-tuk Kompetensi Kepribadian, dari 40 perta-nyaan, 9 pertanyaan dianyatakan drop 
dan 31 pertanyaan valid. Untuk Kompetensi Profesi-onal, dari 40 pertanyaan, 8 pertanyaan dinyatakan drop dan 32 pertanyaan valid. Perhitungan reliabilitas dari keempat kompetensi ini mengguakan Alpha Cronbach dan kriteria batas minimum pernyataan yang diterima adalah $r_{\text {tabel }}=0,361$ jika $r_{\text {hitung }}>r_{\text {tabel}}$, maka butir pernyataan dianggap valid, dan sebaliknya jika $r_{\text {hitung }}<$ $r_{\text {tabel}}$, maka butir pertanyaan dianggap tidak valid yang kemudian butir pernyataan tersebut tidak digunakan atau harus di drop. Ini mem-buktikan bahwa instrumen tersebut valid dan reliabel.

Teknik analisis data yang digunakan da-lam penelitian ini adalah wawancara kepada Guru Pendidikan Jasmani, dimana setiap Guru Pendidikan Jasmani memberikan pernyataan-pernyataan sesuai dengan kondisinya masing-masing, terhadap pembelajaran yang diberikan di sekolah.

\section{HASIL DAN PEMBAHASAN}

Berdasarkan teori yang melandasi pe-nelitian ini mengenai kompetensi guru, pene-liti membatasi hanya meneliti kompetensi pe-dagogik dan kompensi professional. Hal ini dilakukan atas dasar keterjangkauan peneliti-an. Pembahasan penelitian difokuskan pada kompetensi pedagogik dan kompetensi profe-sional.

Dari data yang terkumpul, dapat disimpulkan bahwa dalam kompetensi pedagogik, guru Pendidikan Jasmani Sekolah Dasar dapat dikatakan cukup baik pengasaannya dalam mengenali peserta didik dari aspek fisik, mora, sosial, cultural, emosional, dan intelektual yaitu $63,33 \%$ baik dan 26,7\% cukup. Pemahaman karakteristik peserta didik dilakukan oleh guru bekerja sama dengan guru kelas dan melalui tanya jawab dengan siswa.

Data penguasaan teori belajar dan prinsip pembelajaran diambil dengan melakukan observasi dan analisis dokumen. Observasi dilakukan untuk mengetahui kemampuan guru dalam mengajar baik di kelas maupun di lapangan. Dari hasil pengamatan ternyata kemampuan guru dalam mengajar dapat dikatakan cukup. Hal ini dapat dilihat pada grafik di bawah ini.

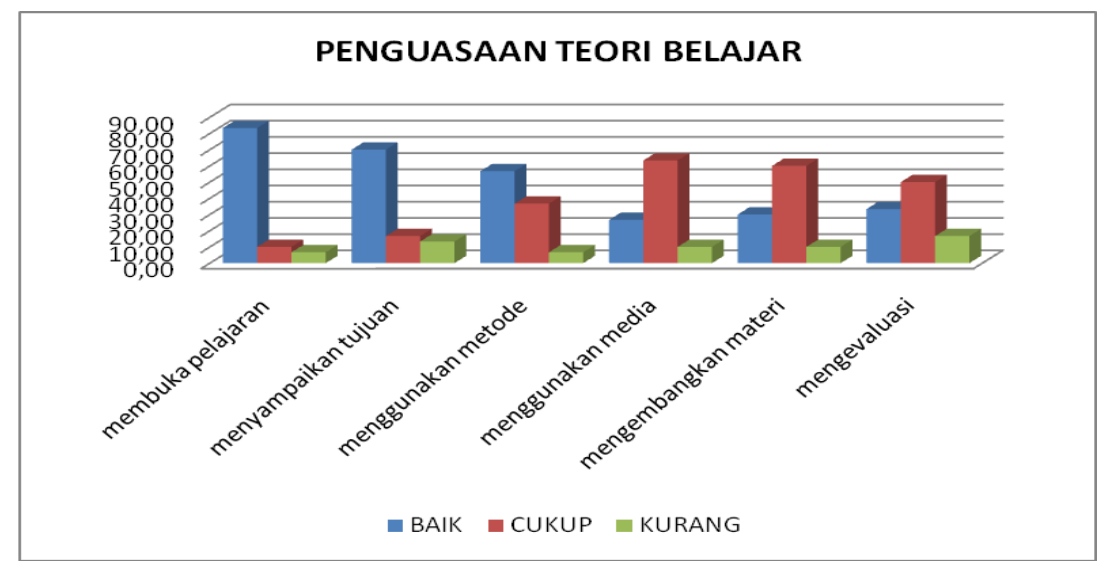

Grafik 1. Sebaran Penguasaan Teori Belajar

Dari grafik di atas terlihat bahwa penggunaan media dan pengembangan materi masih belum memadai. Sementara kemampuan guru dalam pengorganisasian pembelajaran cukup baik.

Kemampuan guru dalam mejabarkan kurikulum terlihat dari kemampuan guru da- lam menurunkan standar isi menjadi silabus dan silabus menjadi Rencana Pembelajaran dapat disimpulkan masih belum memadai. Dari data yang terkumpul, $70 \%$ guru mengalami kesulitan dalam menurunkan Standar Isi ke dalam Silabus. Sementara pada penyusunan Rencana Pembelajaran 
yang diturunkan dari Silabus dapat dikatakan memadai yaitu 83,3\% baik.

Kemampuan guru Pendidikan Jasmani dalam penggunakan teknologi informasi dan komunikasi masih banyak guru yang belum memanfaatkan dalam pembelajaran yaitu ha-nya $26,67 \%$ yang memanfaatkan teknologi in-formasi dan komunikasi dalam pembelajaran pendidikan Jasmani. Kendala yang dihadapi oleh guru sebagian besar adalah sarana dan prasana yang mendukung pemanfaatan tekno-logi informasi tersebut.

Guru Pendidikan Jasmani sangat baik dalam menfasilitasi pengembangan potensi peserta didik untuk mengaktualisasikan potensi yang dimiliki peserta didik. Dari data yang terkumpul $90 \%$ guru menfasilitasi siswa yang memiliki potensi untuk dikembangkan pada prestasi olah raga.

Kemampuan guru memanfaatkan hasil penilaian dan evaluasi untuk kepentingan pembelajaran dilakukan dengan kelompok guru yang ada di sekolah. Hal ini 63,3\% dila-kukan guru bekerja sama dengan guru kelas. Berdasarkan hasil evaluasi tersebut, hamper $90 \%$ guru melakukan tindakan reflektif untuk peningkatan kualitas pembelajaran.

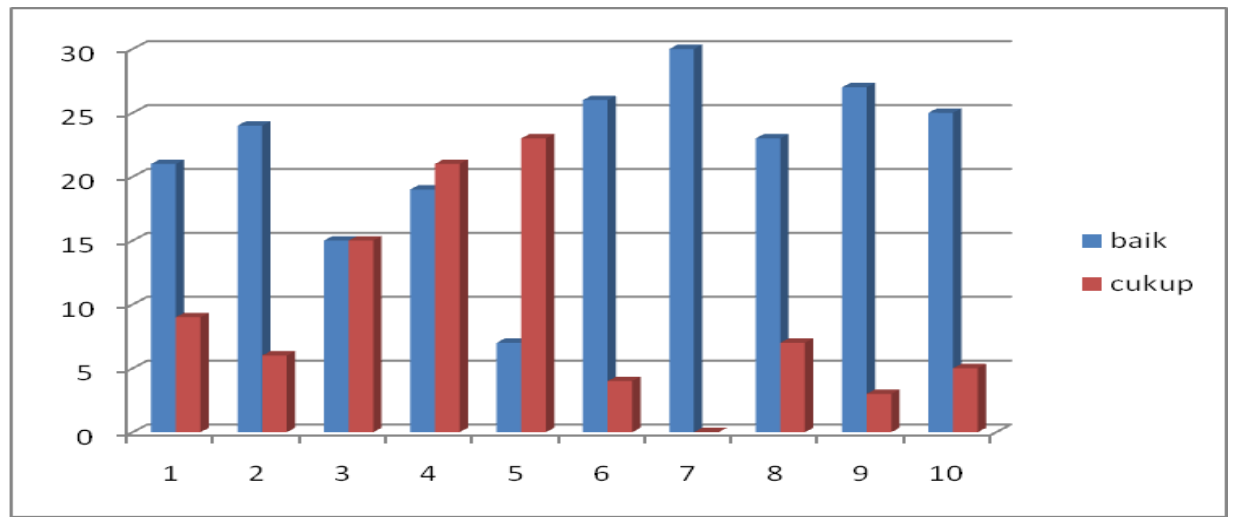

\section{Grafik 2. Sebaran Kemampuan Guru Memanfaatkan Hasil Penilaian dan Evaluasi Untuk Kepentingan Pembelajaran}

Keterangan:

1. Pemahaman peserta didik

4. Pengembangan yang mendidik

7. Komunikasi

10. Refleksi

Berdasarkan data di atas dapat disimpulkan bahwa guru Pendidikan Jasmani masih lemah dalam pemanfaatan teknologi informasi dan penguasaan kurikulum. Kemampuan guru yang sudah memadai adalah menfasilitasi pengembangan potensi siswa untuk mengembangkan olahraga restasi.

Kompetensi professional guru Pendidikan Jasmani terlihat dari penguasaan materi ajar, konsep keilmuan, dan memiliki pola berpikir ilmiah. Dari data yang terkumpul, guru Pendidikan Jasmani dapat dikatakan 83,3\% menguasi materi ajar untuk

\section{Menguasai kurikulum \\ 6. Pengembangan potensi siswa \\ 9. Pemanfaatan evaluasi}

sekolah dasar, tetapi penguasaan konsep ilmu keolah ragaan masih belum memadai yaitu $63,3 \%$ kurang menguasai konsepkonsep keilmuan. Kemampuan dalam menguasai standar kompetensi dan kompetensi dasar dari mata pelajaran Pendidikan Jasmani sudah memadai yaitu $90 \%$.

Kemampuan guru Pendidikan Jasmani dalam pengembangan materi sebagai pembe-lajaran yang kreatif dapat dikatakan belum memadai yaitu $56,67 \%$ selebihnya guru belum mampu mengembangkan materi sebagai 
pembelajaran kreatif. Seperti halnya pada kompetensi pedagogik, guru Pendidikan Jasmani memang belum optimal memanfaatkan teknologi informasi. Dari semua komponen kompetensi professional guru ada beberapa komponen yang masih perlu ditingkatkan. Data tersebut dapat dilihat pada grafik di bawah ini.

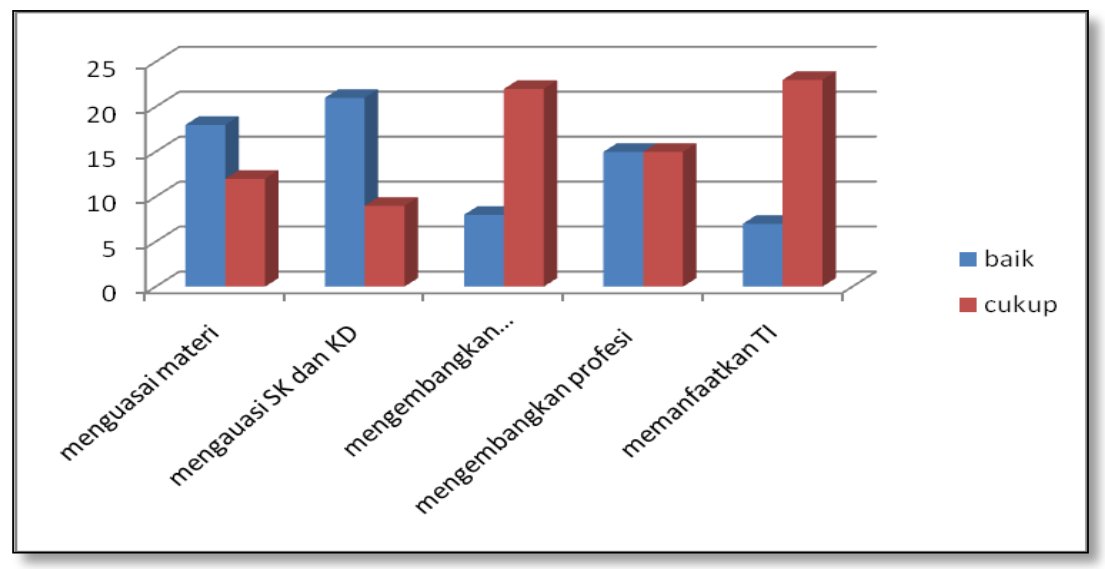

Grafik 3. Sebaran Kompetensi Profesional Guru

Berdasarkan data tersebut di atas, guru Pendidikan Jasmani cukup baik dalam menguasai materi tetapi belum memadai untuk pengembangan professional dan pemanfaatan Teknologi Informasi.

\section{PENUTUP}

Berdasarkan hasil penelitian di atas, peneliti dapat menyimpulkan bahwa guru Pendidikan Jasmani di Sekolah Dasar memiliki kemampuan mengajar bidang Pendidikan Jasmani dengan baik, menguasi materi ajar. Akan tetapi guru tersebut masih lemah dalam penguasaan konsep keilmuan olah raga. Belum semua guru dapat memanfaatkan teknologi informasi dan komunikasi dalam pembelajaran Pendidikan Jasmani. Kemampuan guru dalam mengembangkan diri pada kegiatan profesional juga belum memadai yaitu seperti keikutsertaan guru dalam kegiatan ilmiah misalnya seminar keilmuan olah raga atau penelitian pembelajaran olah raga.

Dengan demikian, peneliti menyarankan bahwa perlu adanya peningkatan kemampuan guru dalam pedagogik terutatama dalam penggunaan media dan teknologi informasi. Dalam kompetensi profesional, perlu ditingkatkan kemampuan pengembangan keprofesi- onalan guru seperti penelitian dan seminar ilmiah.

\section{DAFTAR PUSTAKA}

Depdiknas. (2006). Standar Kompetensi Kepala Sekolah TK,SD, SMP, SMA, $S M K$ \& SLB, Jakarta: BP. Cipta Karya.

(2006). Peraturan Pemerintah No. 14

Tahun 2005 tentang Standar

Nasional Pendidikan. Jakarta:

Departemen Pendidikan Nasional.

Moqvist, L. (2003). The Competency Dimension of Leadership: Findings from a Study of Self-Image among Top Managers in the Changing Swedish Public Administration. Centre for Studies of Humans, Technology and Organisation, Linköping University.

Mary, E. D., \& David G. I. (1995). Professional Teacher Development and the Reform Agenda. ERIC Digest.. 
Jurnal Parameter Volume 29 No. 1 Tahun 2017

DOI : doi.org/10.21009/parameter.291.05

P-ISSN : 0216-26IX

National Board for Professional Teaching Standards. (2002). Five Core Propositions. NBPTS HomePage.

Sudarwan, D. (2002). Inovasi Pendidikan: Dalam Upaya Meningkatkan Profesionalisme Tenaga Kependidikan. Bandung: Pustaka Setia.

Suyanto., \& Hisyam, D. (2000). Refleksi dan Reformasi Pendidikan Indonesia
Memasuki Millenium III. Yogyakarta: Adi Cita.

Usman, N. (2002). Konteks Implementasi Berbasis Kurikulum. Jakarta: PT. Raja Grafindo Persada.

Wiyono, B. B. (2000). "Gaya Kepemimpinan Kepala Sekolah dan Semangat Kerja Guru dalam Melaksanakan Tugas Jabatan di Sekolah Dasar". Jurnal Filsafat, Teori, dan Praktik Kependidikan, Universitas Negeri Malang 